\title{
Evidence-based information guides to rare chromosome disorders for families and professionals
}

\author{
Beverly Searle", Prisca Middlemiss, Sarah Wynn, Maj Hulten \\ From 5th European Conference on Rare Diseases (ECRD 2010) \\ Krakow, Poland. 13-15 May 2010
}

The purpose of this project is to develop reliable, relevant, accurate leaflets for affected families and health (and other) professionals that fill an information gap about rare chromosome disorders. In 2003 Unique surveyed information materials published in the UK about specific rare chromosome disorders: for over $93 \%$ of members, no accessible disorder-specific information was available. Unique asked families what they most wanted to know at diagnosis and what questions remained unanswered. Unique prioritised 66 disorders according to frequency on its database (7,140 member families at February 2010) and absence of existing information accessible to families. Information was compiled from the medical literature, from Unique's database and from detailed surveys sent to member families. Draft texts were reviewed for accuracy by Unique's medical adviser and by medical and genetics professional experts in the specific disorders. Photographically illustrated draft leaflets were vetted for content by families. By early 2010 , leaflets have been developed on 113 rare chromosome disorders including numerical and structural disorders, subtelomere deletions, mosaic disorders, emerging microdeletion and microduplication syndromes and a broad range of less common diagnoses. Twenty-one leaflets have been translated into at least one European language. Many more leaflets are in preparation or planned. Leaflets are available free to families and the professionals who work with them either in print format or online from Unique's website at http://www.rarechromo.org. The leaflets improve families' understanding and acceptance of a rare chromosome disorder and help diminish the acute stress and

*Correspondence: info@rarechromo.org

CEO, Unique - The Rare Chromosome Disorder Support Group,

P.O. Box 2189, Caterham CR3 5GN, UK anxiety associated with diagnosis. They are also proving to be a useful resource for professionals, including health professionals in clinic.

Published: 19 October 2010

doi:10.1186/1750-1172-5-S1-P18

Cite this article as: Searle et al:: Evidence-based information guides to rare chromosome disorders for families and professionals. Orphanet Journal of Rare Diseases 2010 5(Suppl 1):P18.
Submit your next manuscript to BioMed Central and take full advantage of:

- Convenient online submission

- Thorough peer review

- No space constraints or color figure charges

- Immediate publication on acceptance

- Inclusion in PubMed, CAS, Scopus and Google Scholar

- Research which is freely available for redistribution

Submit your manuscript at www.biomedcentral.com/submit
BioMed Central 